\title{
Jókedvvel németül. Tanártovábbképzés és tananyagfejlesztés a budapesti Goethe Intézetben \\ - különös tekintettel a kisgyermekkori nyelvoktatás területére
}

\author{
Morvai Edit \\ Goethe-Institut, Budapest
}

\begin{abstract}
A budapesti Goethe Intézet 2009 és 2012 között több különböző programot dolgozott ki a 6-10 éves korosztály német nyelvi fejlesztése céljára. A nyelvvel való foglalkozás középpontjában a gyerekek számára érdekes tartalmak állnak, a módszereket pedig úgy válogattuk meg, hogy a tanulás a korosztályi sajátosságoknak megfelelően, változatos munkaformákban és felszabadult légkörben folyjon. A tanulmányban ezeket az anyagokat mutatjuk be, bepillantást engedve a megvalósulás folyamatába is.
\end{abstract}

Kulcsszavak: Goethe Intézet, Budapest, német nyelvi fejlesztés, 6-10 éves korosztály, Deutsch mit Hans Hase - in Kindergarten und Vorschule

A Goethe Intézet a Német Szövetségi Köztársaságnak a világ számos országában müködő kulturális intézete1. Célja, hogy elősegítse a német nyelv elsajátítását és a nemzetközi kulturális együttmüködést. Innovatív projektek megvalósításával ahhoz kíván hozzájárulni, hogy egy olyan világban élhessünk, amelyben a nyelvi és kulturális sokszínűség értéket jelent, egyéni és társadalmi szinten segíti a kölcsönös elfogadást és megértést.

A budapesti Goethe Intézet (www.goethe.de/budapest) 1988 óta látja el feladatait. Négy részlege, a kulturális programosztály, a könyvtár és információs központ, a nyelviskola és a magyarra nehezen fordítható Bildungskooperation Deutsch közül az utóbbi foglalkozik kiemelten a magyarországi német nyelvoktatással és annak támogatásával. Legfontosabb partnerei a német nyelvet oktató intézmények, azok pedagógusai és diákjai. Az együttmüködő intézmények sora igen hosszú, az oktatás területén az óvodától az általános és középiskolákon át egészen a felsőoktatásig. Fontos partnerek a normál vagy bővített német nyelvi tanterv szerint dolgozó iskolák mellett a két tanítási nyelvű és német nemzetiségi nevelési-oktatási intézmények. A partnerségekben megnyilvánuló sokszínűség gyümölcsözően hat a mindennapi munkára, amely ugyanakkor változatossága, újszerüsége révén segíti a kapcsolatok bővítését és ösztönzi a minőségi munkavégzést.

\section{Továbbképzések}

A Bildungskooperation Deutsch részleg kiemelt tevékenységi területe a tanártovábbképzés. Ez részben németországi ösztöndíjak révén valósul meg, de nagy létszámban vesznek részt kollégák a hazai továbbképzéseken is. A keretek nagyon különbözőek, az egyhetes intenzív kurzusoktól a néhány órás foglalkozásokig terjednek. A koncepció minden esetben ugyanaz: építünk a résztvevők tapasztalataira, az új ismereteket minden esetben a gyakorlattal szoros összefüggésben adjuk át, majd közösen és egyénileg is átgondoljuk, miként integrálhatók azok a résztvevők mindennapi tevékenységébe. Mindazok az alapelvek tehát, amelyeket a német nyelv oktatása során az iskolai munkában

\footnotetext{
1 A Goethe Intézet központjának honlapja: www.goethe.de
} 
elengedhetetlennek tartunk - mint például a tartalomalapúság, a cselekedtetés, az élményszerüség, a felfedezés öröme, a játékosság stb. -, érvényesülnek a továbbképzéseinkben. Ennek oka az a meggyőződésünk, hogy azok a továbbképzési tartalmak és módszerek, amelyeket a résztvevők közvetlenül megéltek, megtapasztaltak, könnyebben ültethetők át a gyakorlatba, mint azok, amelyekröl csak hallottak, vagy amelyeket más gyakorlata során láttak. Sok esetben persze nem feltétlenül újdonságokkal találkoznak a kollégák továbbképzéseken, hanem olyan módszerekkel, eljárásokkal, amelyeket maguk is alkalmaznak. Ebben az esetben a megerősítés tekinthető a továbbképzés egyik nagyon fontos hozadékának. Máskor a már jól ismert megoldás új kontextusba helyezése jelent egyfajta „aha-élményt”, ami akár egy teljes szemléletváltás kiindulópontja is lehet.

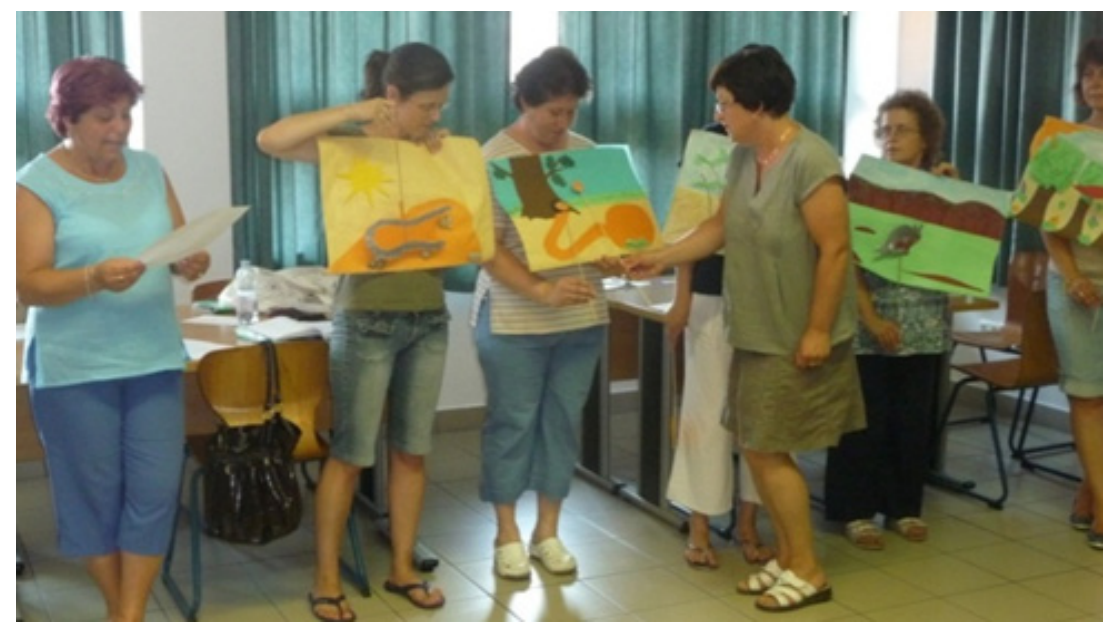

1. kép: Tapasztalati tanulás a Goethe Intézet nyári ösztöndíjas tanártovábbképzésén (Die kleine Maus sucht einen Freund címü történet előadása)

Nagyon fontosnak tartjuk továbbképzéseinken a „Hogyan?” kérdések megválaszolása mellett a „Mit?” és „Miért?” kérdésekkel való foglalkozást is, hiszen önmagukban az érdekes, változatos módszerek nem jelentenek tartós motivációt a tanulóknak. A célok megfogalmazása és azok elfogadása a tanulók által, illetve saját célok kitüzése már a nyelvtanulás korai szakaszában fontos feladata a nevelési-oktatási folyamatnak. A helyes tartalmak megválasztása pedig döntően befolyásolja azt, hogy sikerül-e a tanulók figyelmét akkor is fenntartani, ha a pedagógus nem kívánja (nem is tudja) óráról-órára módszertani „tűzijátékkal” szórakoztatni őket. Továbbképzéseinken nagy hangsúlyt fektetünk a résztvevők közötti tapasztalatcserére és arra, hogy módjuk legyen beszámolni saját jó gyakorlatukról vagy éppen kudarcaikról, kérdéseikröl.

Ugyancsak azzal a szándékkal, hogy útravalóként magukkal vigyék a kollégák, a továbbképzéseket célnyelven tartjuk, de figyelembe vesszük azt, hogy sokszor nehéz a szakmáról idegen nyelven beszélgetni, főként, ha az embernek kevés a gyakorlata ezen a téren és nem kiforrott gondolatokat oszt meg a hallgatósággal, hanem inkább hangosan gondolkodik. A továbbképzések bizonyos szakaszaiban tehát a „felvilágosult egynyelvűség" elvét követjük, feltéve hogy nyelvileg homogén csoporttal dolgozunk. Ezzel egyidejüleg azonban erősítjük a résztvevőkben a célnyelven való kommunikáció igényét és annak a gátlásnak a levetkőzését, hogy inkább nem szólalnak meg vagy szükre szabják mondanivalójukat, ha úgy érzik, nem sikerül gördülékenyen kifejezniük magukat vagy hibákat ejtenek a beszéd során. Az elfogadó környezet megteremtése, a játékosság, a megfelelő hibajavítási technikák alkalmazása stb. mintát jelentenek számukra arra az esetre, amikor nekik kell a diákjaikat bíztatni, hogy merjenek kísérletezni a nyelvvel, hiszen a beszédet csak beszéd közben lehet megtanulni. 


\section{Tananyagfejlesztés}

Részben a tanárkollégákkal ápolt intenzív évközi kapcsolat, részben a továbbképzések során szerzett tapasztalatok mentén kristályosodott ki a budapesti Goethe Intézet érintett munkatársaiban az a meggyőződés, hogy a nyelvoktatás céljairól, tartalmairól és módszereiről vallott nézeteinket úgy tudjuk leghatékonyabban közvetíteni a németnyelv-tanárok felé, ha olyan anyagokkal dolgozunk, amelyek teljes egészében összhangban állnak az elképzeléseinkkel. Kezdetben arra törekedtünk, hogy minél több autentikus anyagot biztosítsunk az iskolák számára. Így született meg a Wanderkoffer- és Wanderausstellung-akciók ötlete (Vándorló kofferek és -kiálllítások) ${ }^{2}$ amely az évek során egyre jobban kinőtte magát. Az iskoláknak lehetősége van a budapesti Goethe Intézettől meghatározott időre egy egész koffernyi filmet, történetet, képes mesekönyvet, társasjátékot stb. kikölcsönözni és az ezekkel végzett munkát a tananyagba integrálni Az anyagokat két célcsoport számára válogattuk: 1-6. évfolyam, illetve 7-12. évfolyam. A felhasználáshoz tanári útmutatókat biztosítunk, így azok a kollégák, akik még nem rendelkeznek elegendő tapasztalattal, támaszkodhatnak a kofferekben található módszertani ajánlásokra. A gyakorlott kollégák ötleteket meríthetnek a kész anyagokból vagy ezektől függetlenül, önállóan, saját elképzeléseik szerint szabhatják a bőröndök tartalmát csoportjaik lehetőségeire és igényeire. A vándorkiállítások ugyanezen az elképzelésen alapulnak. A különböző témák, irodalom, zene, müvészet, környezetvédelem alkalmasak arra, hogy projektnapok keretében az egész iskolát megmozgassák, de lehet szerényebb dimenzióban is gondolkodni és a kiállítások anyagát csupán a német nyelvoktatás színesítésére vagy egy két tantárggyal kooperálva használni. Az egyes kiállításokhoz tartozó és a honlapról is letölthető módszertani ötletek hatékonyan segíthetik a munkát és saját megoldások kidolgozására ösztönöznek.

A tananyagfejlesztés következő lépése az volt, amikor úgy döntöttünk, összeállítunk egy elsősorban 3-4. osztályos tanulóknak szóló, de megfelelően adaptálva más évfolyamokon is alkalmazható Puppenkoffert (Baba-börönd) ${ }^{3}$.

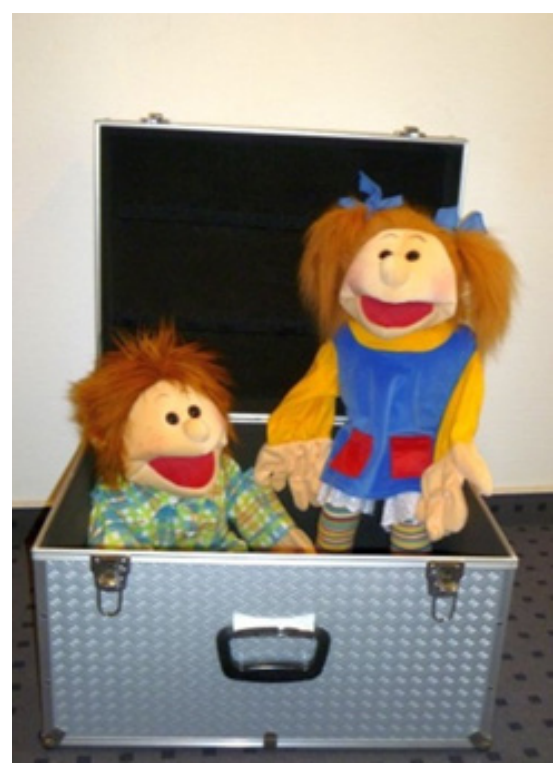

2. kép: Lotte és Fabian, a mini-projekteket tartalmazó Puppenkoffer lakói

2 Wanderkoffer und Wanderausstellungen: https://www.goethe.de/ins/hu/de/spr/unt/kum/stu.html

Puppenkoffer: https://www.goethe.de/ins/hu/de/spr/unt/kum/stu/wak.html 
Azt vettük ugyanis észre, hogy a tanárkollégák gyakran beszélnek arról, hogy projekteket valósítanak meg tanulóikkal a nyelvórákon, de a beszámolóik alapján az volt a benyomásunk, hogy inkább a tevékenységen alapuló nyelvoktatás elképzelését valósítják meg és kevésbé fejlesztik a tanulók projektkompetenciáját. Ezért a Puppenkoffer koncepcióját kettős céllal alakítottuk ki: Egyrészt szerettük volna, hogy a tanulók a német nyelvórán tanultakat egy kvázi-autentikus helyzetben alkalmazzák (a babák Hamburgból érkeznek, kizárólag németül beszélnek és nagyon szeretnék tudni, milyen egy magyar iskola, hogy élnek a magyar kisdiákok), miközben megismerkednek a projektoktatás alapjaival. Másrészt az volt a célunk, hogy a nagyon részletesen, lépésről-lépésre kidolgozott legfeljebb 3-4 tanórában megvalósítható miniprojektek révén a tanárkollégák gyakorlatot szerezzenek a projektek megvalósításában, illetve megerősítést kapjanak, ha már dolgoznak ezzel a módszerrel és ötleteket gyűjtsenek további, a tananyaghoz kapcsolódó mini-projektek kidolgozásához. A Puppenkoffer egyben arra is szolgál, hogy tapasztalatcserére ösztönözze a nyelvtanárokat. A koncepció fontos része a hálózatépítés, ami a végzett munkának megadott szempontok szerinti dokumentálása révén sikeresen megvalósul.

A lelkes visszajelzéseken túl jól bizonyítja ezeknek a kiegészítő tananyagoknak a sikerét, illetve szükségességét az, hogy mind a bőröndök, mind a kiállítások évek óta csaknem folyamatosan úton vannak, s az igény olyan jelentős, hogy időközben minden bőröndből két-két példányt indítunk a tanév elején útnak, sőt az anyagok egy részét partnerkönyvtárainkban is elhelyeztük.

Legújabb kezdeményezésünk, a kisiskolásoknak szóló Märchenmappe zum Erzähltheater (Mese-mappa asztali színházhoz) ${ }^{4}$ is hamar közkedveltté vált. A Goethe Intézet 2013-ban világszerte számos programmal és eseménnyel emlékezett meg arról, hogy 200 éve jelent meg a világ leghíresebb mesegyüjteményének, a Grimm testvérek „Gyermek- és családi meséinek“ első kiadása. A budapesti Goethe Intézet egyebek között gyermekrajz-pályázatot hirdetett ebből az alkalomból. „Az én Grimmmesém" címmel kiírt verseny 6 és 12 év közötti gyerekeknek szólt, akik öt Grimm-mese közül választhattak, és a kiválasztott meséhez négy képből álló sorozatot készíthettek csoportos munkában. A felhívás rendkívül nagy visszhangra lelt: 121 iskolából 574 csoport két hónap alatt több mint 2000 meseillusztrációt küldött be. A szakértői zsüri által kiválasztott legjobb munkákból kiállítást rendeztünk, tizenkét különösen jól sikerült illusztrációból pedig falinaptár készült. A folytatás pedig egy mesemappa elkészítése volt, ami rengeteg pedagógiai potenciált rejt magában. A hordozható, asztali színház az anyanyelvi és idegennyelvi oktatásban egyaránt kiválóan alkalmazható. A képekkel támogatott mese- és történetmondás fejleszti a tanulók beszédkészségét. Miközben áttérnek a felolvasásról a történetmondásra, majd pedig a játékra, nem csak nyelvileg fejlődnek tovább. A cselekményszövés és a játékos tanulás egész személyiségüket megszólítja és alakítja. A német nyelvoktatásban történő alkalmazást a honlapról letölthető módszertani ajánlások segítik.

\footnotetext{
4 Märchenmappe zum Erzähltheater: https://www.goethe.de/ins/hu/de/spr/unt/kum/kin/map.html
} 


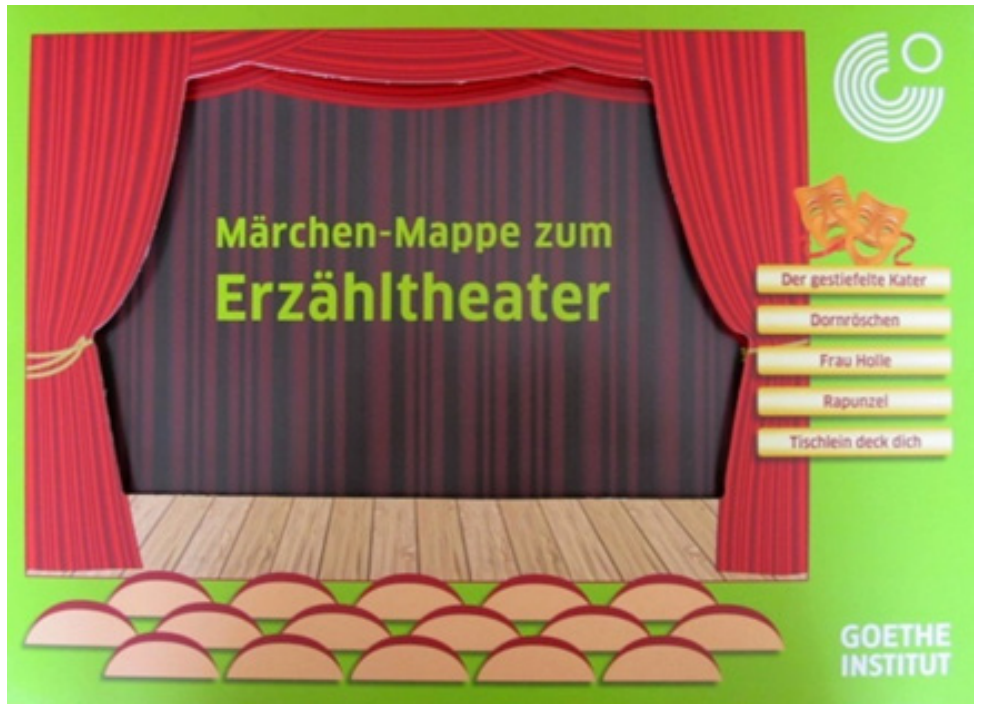

3. kép: Mese-mappa öt Grimm-mesével asztali színházi előadásokhoz

\section{Kisgyermekkori nyelvoktatás a budapesti Goethe Intézetben}

\section{Elméleti alapok}

2008 óta a budapesti Goethe Intézet tevékenységének kiemelt területe a korai nyelvoktatás és az évek során ezen a területen a müncheni központtal szorosan együttműködve egyfajta szakmai vezető szerepet vívott ki magának. A Puppenkoffer és a Märchenmappe zum Erzählteater projektek ennek a törekvésnek a jegyében születtek. Emellett egy másik szálon elindult egy szisztematikus fejlesztő munka, amelynek eredményeképp létrejött egy három részből álló, a célkitűzések, tartalmak és módszerek tekintetében koherens egységet képező „taneszköz-család”.

Amikor a Goethe Intézetben korai nyelvoktatásról beszélünk, minden esetben abból a kutatások által igazolt és a mindennapokban megtapasztalható tényböl indulunk ki, hogy a kisgyermek másképp tanulja, illetve sajátítja el az idegen nyelvet, mint idősebb társai ${ }^{5}$. A nyelvtanulási, nyelvelsajátítási folyamat ebben az életkorban még sok hasonlóságot mutat az anyanyelv elsajátításával, bár természetesen a körülményekből adódóan eltérések is vannak. Gyakran és szívesen használjuk az oktatás kifejezés mellett, illetve helyett a nyelvi nevelés fogalmát azért, hogy világossá tegyük: számunkra az idegen nyelvvel való foglalkozás kisgyermek korban sokkal inkább minőségi, mint mennyiségi kérdés.

A hazai kisgyermekkori nyelvoktatással kapcsolatban rengeteg a nyitott kérdés. A kötelező idegennyelv-oktatás kezdete Magyarországon az általános iskola negyedik évfolyama. A Nemzeti Alaptanterv lehetővé teszi az ennél korábbi kezdést, amennyiben az iskola biztosítani tudja a szükséges feltételeket ${ }^{6}$. Az oktatási intézmények bizonyos keretek közt arról is szabadon dönthetnek, hogy milyen idegen nyelvvel kezdjenek. Ez a megengedő

5 Kovács Judit $A$ gyermek és az idegen nyelv címú munkájában (Eötvös József Könyvkiadó, 2009) részletesen tárgyalja a 10 év alatti korosztály idegennyelv-tanulásának sajátosságait.

6 Vonatkozó bekezdés a Nemzeti Alaptantervben: „Az élő idegen nyelvet a közoktatásban részt vevő minden diáknak kötelező tanulnia a negyedik évfolyamtól a tankötelezettség végéig. Meghatározott feltételek teljesülésekor az iskolák a negyedik évfolyamot megelőzően is elkezdhetik a nyelvtanítást". In: 243/2003. (XII. 17.) Korm. rendelet a Nemzeti alaptanterv kiadásáról, bevezetéséröl és alkalmazásáról. 38. old., http://www.nefmi. gov.hu/letolt/kozokt/nat_070926.pdf. 
hozzáállás egyrészt jó, hiszen sok gyermek számára biztosítja az idegen nyelvvel és kultúrával való korai megismerkedést. Másrészt nyitva hagy alapvető fontosságú kérdéseket illetve azok megválaszolását az iskolákra bízza: Mikortól, milyen óraszámban és időkeretben célszerü tanítani az idegen nyelvet? Melyek azok a feltételek, amelyeknek mindenképpen teljesülni kell? Ki állja a költségeket? Mikortól érdemes bevezetni a második idegen nyelv tanulását? A szabályozás hiánya az évek során oda vezetett, hogy a kötelező nyelvoktatást megelőző időszakban a nyelvvel való foglalkozásnak számos mintázata létezik és (részben emiatt) az iskoláknak nem mindig sikerül biztosítani a zökkenőmentes átmenetet a kötelező nyelvoktatást megelőző és az azt követő időszak között ${ }^{7}$.

Amikor a Goethe Intézet úgy határozott, hogy tananyagfejlesztéssel reagál a továbbképzések során megnyilvánuló igényre, miszerint a hatékony kisgyermekkori nyelvoktatáshoz szükség van olyan tananyagokra, taneszközökre, amelyek azokat az alapelveket ültetik át a gyakorlatba, amelyek mentén megvalósulhat a minőségi nyelvoktatás és ezáltal segítik a pedagógusokat a mindennapi munkában. Könnyen hozzáférhető, részletesen kidolgozott, tanuló- és tanárbarát anyagokra vágyott a szakma, ami érthető is, hiszen hosszú távon nehezen várható el a mégoly tapasztalt pedagógusoktól is, hogy a tanterv elkészítése mellett maguk állítsák össze csoportjaik számára a tananyagot is, azaz kitalálják a koncepciót, összegyűjtsék és didaktizálják a forrásokat, elkészítsék a szemléltető eszközöket stb. Ez még egy jól müködő munkaközösség számára is komoly kihívást jelent, különösen akkor, ha figyelembe vesszük, mekkora nyomás nehezedik a pedagógusokra, hányféle területen kell megfelelniük.

A munka első fázisában még egyszer nagyon alaposan átgondoltuk, melyek azok a reális célok, amelyek az általunk fejlesztett anyagok segítségével elérhetők. Az idegen nyelv tanításának, tanulásának céljait három dimenzióban fogalmaztuk meg:

1. a tanulók idegennyelvi kommunikatív kompetenciájának megalapozása és fejlesztése,

2. a tanulók interkulturális nevelése,

3. a tanulók önálló nyelvtanulóvá nevelése.

A korai nyelvoktatás mindhárom területen hatékonyan hozzájárulhat a célok eléréséhez. A fenti célkitüzések keretén belül a kisgyermekkori idegennyelv-oktatás speciális céljai felfogásunk szerint a következők:

- Bővítse azoknak a lehetőségeknek a sorát, amelyek révén a tanulók már ebben a korai szakaszban megkezdhetik a felkészülést a megváltozott és állandóan változó világunkra.

- Felkeltse a tanulókban a nyelv, illetve a nyelvek iránti érdeklődést és kifejlessze bennük azt az érzést, miszerint a nyelvtanulás öröm.

- Megalapozza és fejlessze a tanulók idegen nyelvi ismereteit és lehetőséget nyújtson nekik a nyelvnek mint a kommunikáció eszközének a kipróbálására és alkalmazására.

- Lehetőséget adjon a tanulóknak tudatosabban szemlélni és használni saját anyanyelvüket.

- Megismertesse a tanulókat egy sor tantárgy-specifikus és tantárgyakat átfogó stratégiával és technikával, amelyek segítik őket abban, hogy hosszú távon önálló nyelvtanulóvá váljanak.

- Hozzájáruljon a tanulók személyiségének sokoldalú fejlesztéséhez, ösztönözze emocionális, kreatív, szociális, kognitív és nyelvi képességeik alakulását.

A tartalmak meghatározásánál a következőket gondoltuk át: A korszerü idegen-

\footnotetext{
7 A 2009-ben készült Idegennyelv-oktatás az általános iskolák 1-3. évfolyamán címü kutatás átfogó képet ad a kialakult helyzetről: http://www.nefmi.gov.hu/nemzetkozi-kapcsolatok/aktualis/idegennyelv-oktatas.
} 
nyelv-oktatásban nem a megtanulandó nyelvi jelenségek meghatározott köréböl indulunk ki, tehát nem ezekhez keresünk, illetve 'gyártunk' megfelelő tartalmakat, hanem olyan témákat és a témákhoz olyan anyagokat választunk, amelyek egyrészt összhangban állnak a gyermekeknek a világról szerzett ismereteivel, tapasztalataival, érdeklődésével és kommunikatív szükségleteivel, másrészt árnyaltan mutatják be a célnyelvi országokban elő emberek, közülük is elsősorban a hasonló korú gyermekek életét. Alapvetően tehát nem arról van szó, hogy a tanulók hiányzó, illetve minimális idegen nyelvi kompetenciájára való tekintettel a világot leegyszerüsített formában mutatjuk be nekik vagy akár a már ismert anyanyelvi világot idegen nyelven újra fogalmazzuk. Sokkal inkább az a feladatunk, hogy az új nyelv segítségével új tartalmakkal ismerkedjenek meg a tanulók, ami adott esetben azt is jelentheti, hogy a látszólag ismert világra az idegen szemével tekintenek, mintegy újra felfedezve azt.

Olyan anyagokkal kell dolgoznunk, amelyek felkeltik a tanulók kíváncsiságát, elgondolkodtatják vagy éppen megnevettetik őket és lehetőséget nyújtanak nekik arra, hogy szabadon szárnyalhasson a fantáziájuk, kibontakozhasson a kreativitásuk. A jól megválasztott tartalom, a megfelelő téma minden más tényezőnél alkalmasabb arra, hogy tartósan motiválja a tanulókat.

A módszerek tekintetében olyan korábban már említett alapelvekre építettünk, mint a tartalomalapúság, a narrativitás, a tevékenységközpontúság, az élményszerüség, a játékosság. Állandóan szem előtt tartottuk, hogy a célok és tartalmak mellett a módszereket is szoros összefüggésben kell kezelni a tanulók életkori sajátosságaival s az ezek tükrében változó készségeivel, képességeivel, érdeklődésével, igényeivel. Ugyanakkor nem felejthetjük el, hogy az életkori sajátosságok csak átlagos viszonyítási alapot jelentenek. Mind a biológiai, mind a kognitív és emocionális fejlődés nagy egyéni különbségekkel zajlik, azaz az életkori jellemzőket rendkívül széles skálán színezik az individuális adottságok.

Fejlesztő munkánk során mindvégig kiemelt szerepet tulajdonítottunk a hangulati tényezőnek. Igyekeztünk mind a tartalmakat, mind a módszereket úgy megválasztani, hogy a tanulók örömüket leljék a nyelvben és annak elsajátításában. Szeressék azt, amit tanulnak és azt is, ahogyan ezt teszik. Ahhoz, hogy a tanulók aktívan részt vegyenek a munkában és élvezzék azt, olyan kellemes légkört kell teremtenünk, amelyben a jókedv és az öröm dominálnak, s ahol minden tanulónak lehetősége van arra, hogy sikerélményre tegyen szert.

\section{Gyakorlati megvalósulás}

A fentiekben leírtak figyelembevételével születtek meg 2008 és 2014 között a budapesti Goethe Intézetben azok a tananyagok, taneszközök, amelyekkel nem csak hazákban, hanem a Goethe Intézet központja támogatásának köszönhetően a világ számos országában dolgoznak.

Leginkább a Deutsch mit Hans Hase - in Kindergarten und Vorschule címü taneszközcsomag terjedt el az óvodákban, iskola-előkészítő csoportokban és az általános iskolák első osztályában8.

8 „Deutsch mit Hans Hase in Kindergarten und Vorschule” címü taneszközcsomag: https://www.goethe.de/ins/ hu/de/spr/unt/kum/kin/dhh.html 


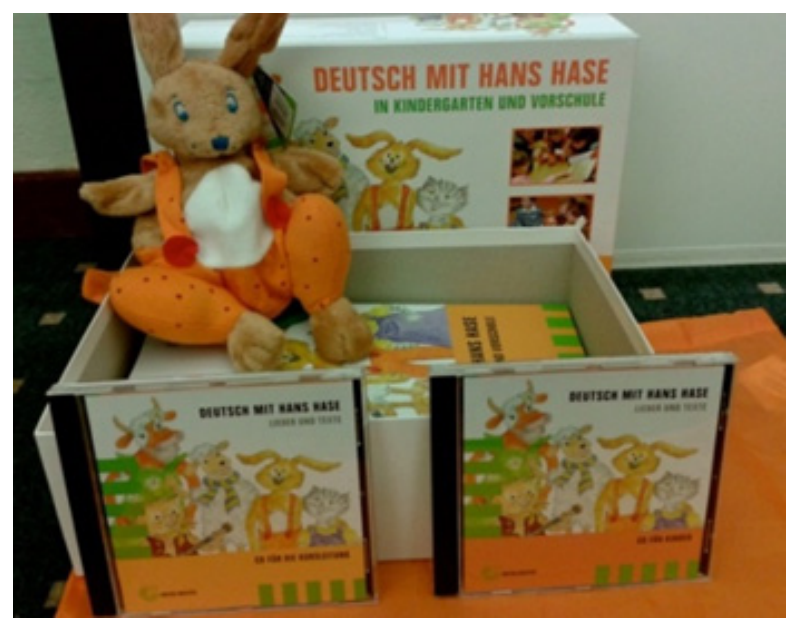

4. kép: Deutsch mit Hans Hase in Kindergarten und Vorschule - játékos német nyelvi program

A 6-8 éves korosztálynak szóló játékos nyelvi program a gyermekeknek az új iránti természetes érdeklődésére épít. Az idegen nyelv elsajátítása az anyanyelv elsajátításához hasonló módon történik: hallás, látás és (nyelvi) cselekvés útján. A gyerekek játszanak, énekelnek, táncolnak, verselnek, barkácsolnak és még sok más tevékenységet végeznek, miközben ismerkednek az idegen nyelvvel.

E tevékenységekben támogatja őket Hans Hase, aki kizárólag németül beszél, így ha bárki szeretné megismerni őt, a családját és a barátait, megtudni, hol lakik, mit szeret és mit nem, milyen játékokkal játszik, hogyan utazik el családjával megünnepelni Rosi nagynénje születésnapját, milyen sportokat kedvel stb., „kénytelen” nyelvet váltani.

A Deutsch mit Hans Hase - in Kindergarten und Vorschule címü német nyelvi program egyik legfontosabb célkitüzése, hogy a gyerekek pozitív érzelmeket társítsanak az idegen nyelvvel való foglalkozáshoz. Ez jó alapokat teremt ahhoz, hogy a későbbiekben motivált nyelvtanuló váljon belőlük.

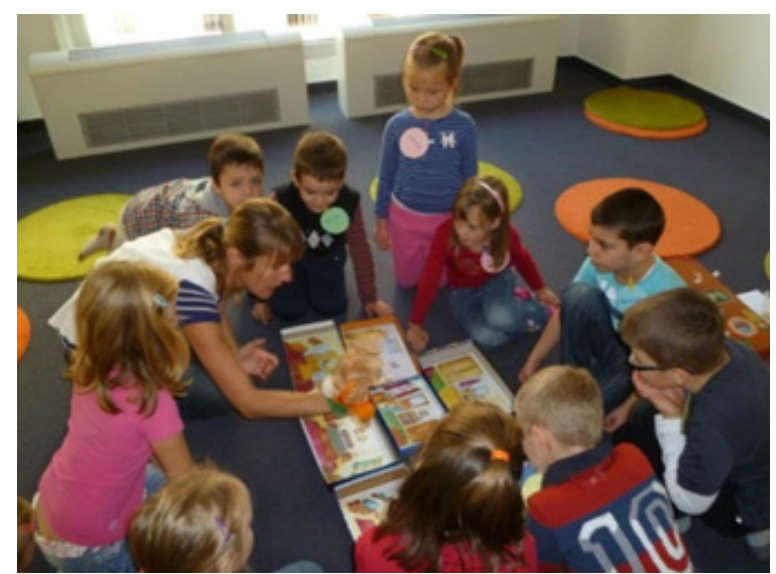

5. kép: Építsük meg együtt Hans Hase házát - kezdő gyermektanfolyam a Goethe Intézetben

Már a fejlesztéssel párhuzamosan három óvodai nagycsoportban zajló kipróbálás során látható volt, hogy a Hans Hase-történet számos ponton bővíthető és ilyen formában alkalmas arra, hogy a németet mint idegen nyelvet alacsony óraszámban tanulókon kívül olyan diákok is foglalkozzanak vele, akik intenzívebb programok keretében tanulják a német nyelvet. 
Ennek az igénynek a nyomán születtek meg azok a német nyelvi modulok, amelyek a Goethe Intézet gyermektanfolyamain és néhány általános iskolai csoportban való kipróbálást követően nemrégiben kerültek fel a budapesti Goethe Intézet honlapjára Deutschmodule für Kinder címmel ${ }^{9}$.

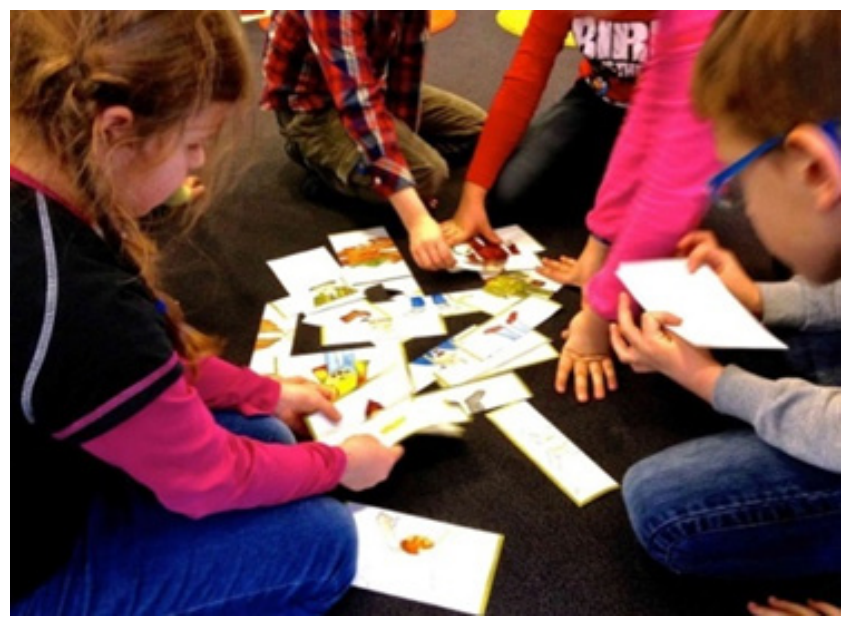

6. kép: Ki kicsoda-puzzle - játékos szótanulás

A modulok szorosan illeszkednek a Hans Hase-taneszközcsomag tartalmi koncepciójához, de attól függetlenül is felhasználhatók. Történetek, dalok, versek szolgáltatják az egyes modulokhoz a kiinduló alapot. Ezekhez kapcsolódik a módszertani útmutató, mely követi a Hans Hase-taneszközcsomag jól bevált felépítését: tartalmak, célok, eszközök, óratervek. Minden más, ami a 3-5 tanórás modulok megvalósításához szükséges, mint például színes képek, feladat- és barkácslapok, társasjátékok stb. ingyenesen letölthetők a Goethe Intézet honlapjáról. Ízelítőül csupán néhány téma a hozzá kapcsolódó autentikus anyaggal:

- Wohnen - Johannes Trojan: Die Wohnung der Maus

- Berufe - Der arme Schneider (jüdisches Märchen)

- Wetter - Eric Carle: Kleine Wolke

- Sommerurlaub - Volker Rosin: Ich packe meinen Urlaubskoffer.

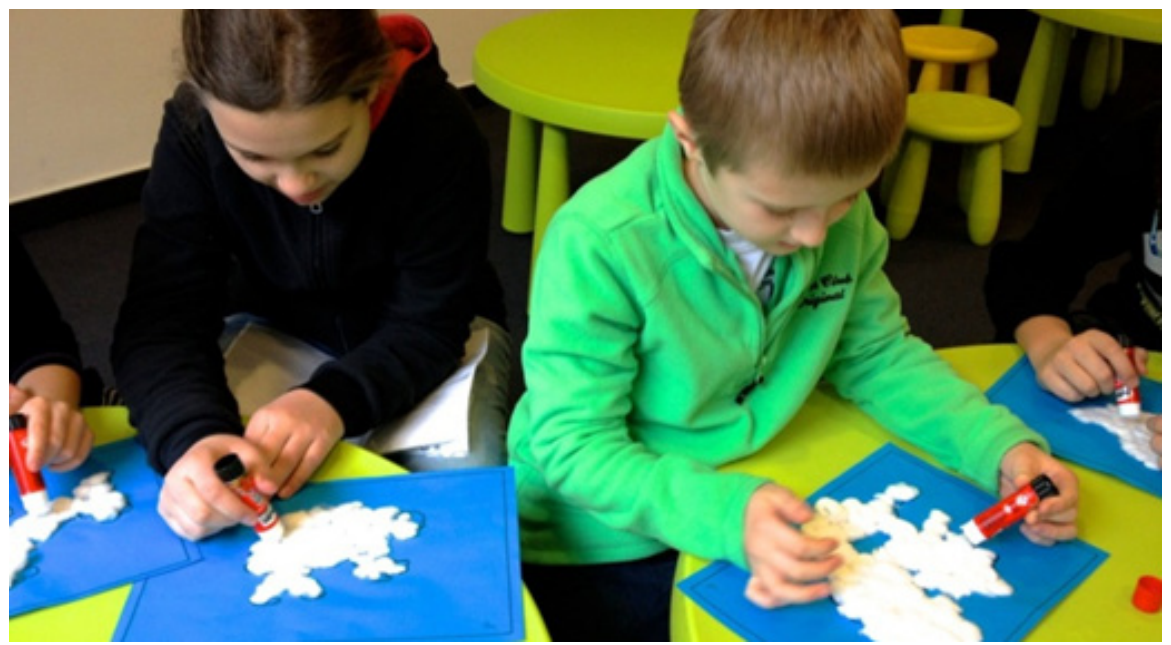

6. kép. Kleine Wolke - egy történet feldolgozása a Deutschmodule für Kinder sorozatból

${ }^{9}$ Deutschmodule für Kinder: https://www.goethe.de/relaunch/ins/cz/de/spr/unt/kum/dfk/dfk.html 
A modulok egyebekben nem csupán a Hans Hase-taneszközcsomaghoz kapcsolódnak, hanem a mese-mappához is, például a „Märchenfest” címú modulban a mese-mappában is megtalálható „Dornröschen” képsorozattal dolgozunk, a „Freundschaft” témakörben pedig javasoljuk a feldolgozás során az asztali színház módszerének kipróbálását. $A$ modulok egyúttal némiképp elő is készítik azt a munkát, amit később a „Puppenkoffer”-ben található mini-projektek keretében végezhetünk a tanulókkal. Itt még erősen irányított formában valósulnak meg a témafeldolgozások, a „Puppenkoffer” alkalmazása során azonban már tudatosan építünk a tanulók önálló, felelös közremüködésére.

A sorban a harmadik, legújszerübb és számunkra is a legnagyobb és legérdekesebb kihívást a Jeder ist anders - Musical für Kinder című taneszközcsomag elkészítése jelentette ${ }^{10}$.

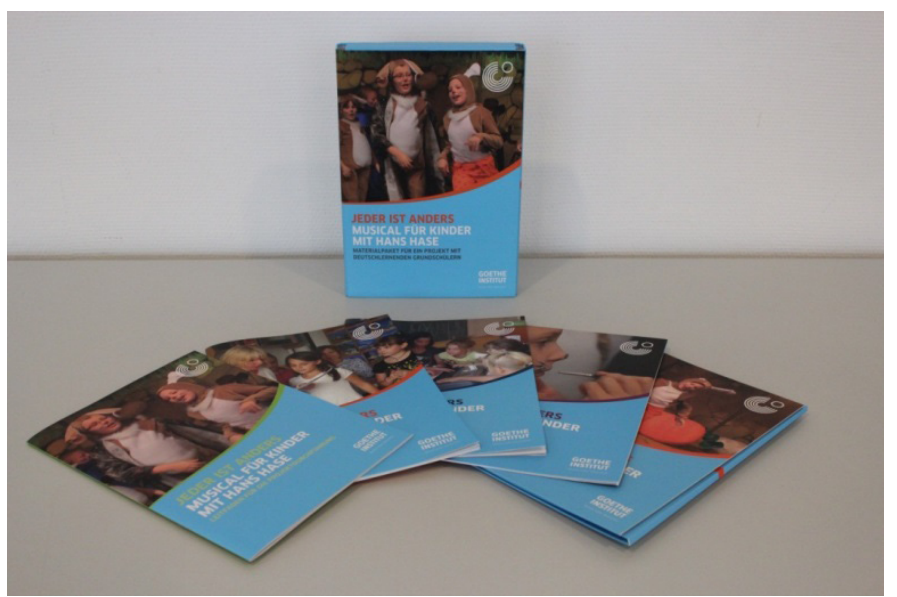

7. kép: Jeder ist anders - Musical für Kinder címủ német nyelvi projekt

A musical-projekt olyan 8-12 év közötti gyerekek számára készült, akik rendelkeznek alapvető, A1 szintű német nyelvismerettel, szívesen játszanak, énekelnek és táncolnak és örömmel vesznek részt egy kreatív nyelvi kalandban. A projekt megvalósítható egy iskolai osztály tanulóival vagy akár egy olyan tanulócsoporttal is (például szakköri formában), amelynek tagjai különböző osztályokba, évfolyamokba járnak. A tanárok szempontjából fontos, hogy nyitottak legyenek az új kihívások iránt, ne riadjanak vissza a feladat komplexitásától és élvezzék az iskola és kollégáik támogatását. Ennél több nem is kell, mert az anyagot úgy álítottuk össze, hogy minden szükséges segítséget megkapjanak a projekt kivitelezéséhez. Igény esetén a Goethe Intézet a projekt fejlesztése során készült díszleteket és jelmezeket is szívesen rendelkezésre bocsátja.

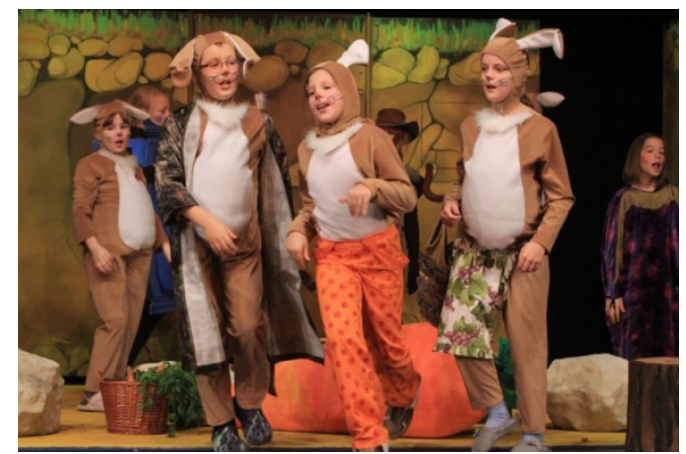

8. kép: Nyelvtanulás zenés-táncos formában

10 Jeder ist anders - Musical für Kinder: http://www.goethe.de/ins/hu/bud//hr/dhh/jia/deindex.htm. 
A projekt legfontosabb célkitüzése, hogy diákok és tanárok partnerként dolgozzanak együtt, s közösen hozzanak létre egy olyan produktumot, ami mindnyájuk számára örömet és sikert jelent. A hazai és nemzetközi tapasztalatok is azt bizonyítják, hogy a megvalósítás során jelentős mértékben fejlődnek a tanulók nyelvi ismeretei, magabiztosabban használják az idegen nyelvet. A projekt megmozgatja a fantáziájukat és felébreszti bennük a kreativitást, valamint elősegíti a témaközpontú és tantárgyakat átfogó tanulást, teret ad a diákok személyiségének fejlődéséhez és fokozza a nyelvtanulási kedvet.

\section{Végezetül...}

A Goethe Intézet korai nyelvoktatás témában továbbképzéseket tartó és tananyagokat fejlesztő teamjének sokéves tapasztalata szerint - és ezt bizonyítják a már említett 2009-es felmérés adatai is - a korai nyelvoktatás területén dolgozó pedagógusok többsége világosan látja a korai nyelvoktatásban rejlö lehetőségeket és eredményesnek értékeli a munkáját. Nagyon jó mühelyek és csapatok müködnek országszerte és egyre több a példaértékủ gyakorlat. A további sikeres munka érdekében törekednünk kell arra, hogy lehetöleg mindenütt, ahol korai nyelvoktatással foglalkoznak, teljesüljenek bizonyos minimális feltételek. Mindenképpen szükség van egy jól átgondolt, folyamatos fejlődést biztosító idegen nyelvi programra, olyan nyelvtanárokra, akik biztos nyelvtudással rendelkeznek és szakmailag jól képzettek, támogató iskolai környezetre és olyan szülökre, akik maguk is meg vannak győződve a kisgyermekkori nyelvtanulás hasznosságáról. 